\title{
Remittances and Labor Supply: Evidence from Tunisia
}

\author{
Hajer Habib ${ }^{1}$ (D)
}

Received: 24 October 2020 / Accepted: 19 January 2022

(c) The Author(s), under exclusive licence to Springer Science+Business Media, LLC, part of Springer Nature 2022

\begin{abstract}
The objective is to present our contribution to the theoretical literature through a simple theoretical model dealing with the effect of remittances on the labor market of the origin countries and on the other hand to test this relationship empirically in the case of Tunisia. The methodology used consists of estimating a panel of the nine main destinations of the Tunisian migrants in Europe between 1997 and 2017. The empirical results show that the main factors explaining the decision to emigrate are the economic factors related mainly to the income differential, the demographic factors related to the differential age structure of the origin and host populations, and the cultural factors linked basically to the language mastery. Indeed, the migrant stocks are one of the main determinants of the remittances to Tunisia. But there are other variables that do not lack importance such as the economic conditions linked by the host countries. This shows that Tunisian migrants react more to economic conditions in European countries than in Tunisia. The economic situation of European countries dominates the number of emigrants as an explanatory factor for the amount of transfers from Tunisian emigrants. Similarly, the results confirm that an increase in remittances significantly reduces the demand for employment and therefore increases the unemployment rate. This positive correlation reveals that the impact of demographic changes on the effect of remittances occurs through an increase in unemployment due to the aging of the population, which coincides with the case of Tunisia going through a demographic transition period.
\end{abstract}

Keywords International migration · Remittances - Labor market participation · Demographic changes · Tunisia

JEL Classification F22 · F24 · J21

Hajer Habib

hajerhabib.k@gmail.com

1 Faculty of Economic Sciences and Management of Tunis, University Farhat Hached,

El Manar II, Tunisia 


\section{Introduction}

With economic, social, and demographic consequences, international migration is an important debate for both developed and developing countries. In this paper, we will treat one of the most important consequences of international migration, namely the migrants' remittances. With globalization, migratory remittances have evolved rapidly over the last 10 years. These remittances to developing countries increased over the period 2000-2010 by around 270\%. In 2019, official remittances recorded more than $\$ 716$ billion, $70 \%$ ( $\$ 554$ billion) of which went to developing countries, after a decrease by around $7 \%$ (from $\$ 716$ billion in 2019 to $\$ 665$ billion in 2020), following the global health crisis of coronavirus (COVID-19). In low- and middle-income countries, the projected decline is from $\$ 554$ billion to $\$ 508$ billion, a decrease of $7.1 \%$ (World Bank, 2020). These foreign financial flows come from almost 250 million migrants in the world, who have kept links with their origin country. During the last years, remittances have become the major source of external financing for developing countries, after foreign direct investment (FDI) (World Bank, 2019a; Ekanayake \& Moslares, 2020). Unlike other private capital flows, remittances tend to be stable and increase during periods of economic downturn and natural disasters (Bettin et al., 2014; Chami et al., 2003; Edelbloude et al., 2017; Yang, 2008). The literature shows that most studies highlight the altruistic motivation of migrants to send remittances to their home countries. As a result of this assumption, remittances play a smoothing role when the economy of the home country suffers a shock. Indeed, they can be an important lifeline for development supporting adaptation to crises (Ratha, 2005; World Bank, 2020; Gagnon, 2020).

The international context of remittances shows that the latter constitutes an important source of funding. The remittances to Tunisia do no escape to this logic. Indeed, the Tunisian diaspora abroad represents about one tenth of the Tunisian population. The stock of Tunisian migrants passes from about 698,000 in 2000 to around 1325.7 in 2017, according to statistics from the Ministry of Social Affairs of Tunisia. Europe remains the main destination of Tunisian emigrants, according to the country's official statistics. More than $80 \%$ of Tunisian emigrants are moving towards Europe (1300), especially in France, with a share of $38 \%$ of the Tunisian diaspora abroad $(700,000)$ (Ministry of Foreign Affairs of Tunisia), followed by Italy and Germany as European destinations, although Libya was a major Arabic destination for Tunisians before the revolution.

The remittances sent by Tunisian migrants have continued to evolve since the 1980s. They have increased between 2000 and 2017 from about 1091.1 million dinars to about 3983.8 million dinars (Ministry of Foreign Affairs of Tunisia). As in all countries of the world, remittances to Tunisia recorded a significant decline of $-14.8 \%$ in 2020 compared to the previous year due to the COVID-19 health crisis. The remittances from Tunisians to their home country increase at the same rate as the migrant stock. These flows of remittances from four host countries of Tunisian migrants (France, Italy, Germany, and Belgium) represent more than 
$90 \%$ of the total remittances received from Europe in 2017 (Ministry of Foreign Affairs of Tunisia). According to data from the Central Bank, remittances that are provided by Tunisians resident in France are more than $40 \%$ in 2017 . However, the economic crisis and high unemployment in European countries will continue to depress remittances of the Tunisian diaspora. The share of remittances from Tunisians in the country's gross domestic product (GDP) was $4.5 \%$ in 2011 . They exceed foreign direct investment (FDI), which accounts for $2.6 \%$ of GDP for the same year. This share of remittances increases each year and represents around 5 to $6 \%$ of Tunisian GDP in 2017 . However, these figures only partially represent the exact amounts of the remittances since a large part passes through informal channels (Freund \& Spatafora, 2005). For example, David and Marouani (2018) show that only $5 \%$ of Tunisian migrants' remittances pass through banks, so a significant portion of these flows enters Tunisia through informal channels.

The geographical and cultural proximity of Europe is the pull factors that facilitate the migration of Tunisians to European countries in order to seek a better life outside their origin country. Indeed, the push factors of Tunisians to leave their country are mainly, unemployment and institutional and political conditions (Zimmermann, 1996). Indeed, unemployment has been considered among the major problems affecting political stability in Tunisia. Over the past few years, Tunisia's level of unemployment has been the main determinant of emigration, exceeding $18 \%$ in 2011 . It recorded a remarkable decline in 2018, but still at double-digit levels of $15.2 \%$ (National Statistics Institute). In this context, David and Marouani (2015) prove the conclusion that the migration of Tunisian workers can play an important role in reducing the unemployment rate through the reduction of the active population.

In recent years, different angles of remittances have been analyzed by researchers, mainly their impacts on origin countries. While most remittances go to developing countries, around $70 \%$ of total remittances, there is a clear distinction between remittances from both sides of countries. In 2015, the average rate of remittances in GDP was $2 \%$ for developing countries against only $0.6 \%$ for developed countries (Azizi, 2018).

Given the increased volume of remittances to developing countries, a large literature shows that these financial flows play an important and effective role in reducing poverty and inequality (Acosta, 2006; Adams \& Cuecuecha, 2013; Adams \& Page, 2005; Ekanayake \& Moslares, 2020; Majeed, 2015; Vacaflores, 2018). These nonwage incomes also continue to improve the level of investment and consumption (Adams, 2009; Azizi, 2018; De Haas, 2006; Orozco, 2012). However, the studies of the relationship between remittances and the labor market conclude that these remittances have two contradictory effects on the recipient economies. On the one hand, they may have a "disincentive effect" on labor supply in the cases where transfer income substitutes for income from work, which increases the unemployment rate (Acosta, 2011; Chami et al., 2018; Damon, 2009; Funkhouser, 1992; Murakami et al., 2021; Ndiaye et al., 2016; Schumann, 2013). On the other hand, if they invest in the long term, remittances increase the rate of realization of investment projects through the accumulation of capital. This can lead to job creation in developing 
countries (Drinkwater et al., 2003). In addition, this work does not take into account the demographic transition and their direct impact on migration and the labor market in developing countries. Indeed, Özden and Schiff (2007) show that an aging population characterizes most developed countries, whose labor force is expected to decline over the next two decades, following a peak expected in 2010. Thus, developing countries are characterized by a more rapid increase in the working age population. This imbalance creates a strong labor supply in developing countries and a high demand for workers in the labor markets of developed countries. It is further exacerbated by the strong income differential between the North and South countries, especially for unskilled and low-unskilled workers. Thus, Harris and Todaro (1970) and Jennissen (2000) predict that the unequal distribution of wages between developed and developing countries is considered to be the most important explanatory factor of the labor movement.

So our objective is to analyze the impact of remittances on the unemployment level in developing countries by trying to integrate the demographic change channel and to take into account the circumstances of the developed economies. The main question we are trying to answer is: What are the effects of remittances on the labor supply of recipient households in the home economies given the demographic changes on both the host and the origin side? And can it be a factor in targeting long-term unemployment?

Our empirical strategy addresses the methodological approach where international migration, remittances, and labor market participation are likely to be taken simultaneously since these variables are strongly related. Thus, the use of a model with three simultaneous equations, estimated for Tunisia and the nine main host countries of Tunisian migrants in Europe, aims to show a weak direct effect of Tunisian remittances on the incentive to participate in the labor market in Tunisia. And, an indirect effect shows a positive correlation between remittances and the unemployment level. This correlation reveals that the impact of demographic change on the effect of transfers occurs through an increase in unemployment due to the population aging, which coincides with the case of Tunisia going through a period of demographic transition.

Following these results, appropriate policies can be implemented to integrate migratory remittances into Tunisia's development policies. The country's decision-makers can benefit more from the Tunisian migratory potential through the establishment of different means allowing Tunisian migrants to direct their transfers for investment purposes in their origin country in order to increase the capital per capita and to reduce the unemployment rate in the coming years.

The paper will be divided into three sections. The first section will present the main theoretical arguments explaining the impact of remittances on the labor market in the home economies and will focus on a simple theoretical model. The second section will be the subject of an empirical application in the Tunisian case. This section will also focus on the results of a three-stage least squares (3SLS) panel regression, as well as the interpretations of these results. Finally, the third section will conclude this work and examine the policy implications. 


\section{Migrants' Remittances and Labor Market: Theoretical Aspects}

\section{Literature Review}

International migration affects both host and home economies. Indeed, if the neoclassical approach (Harris \& Todaro, 1970) considers the migratory phenomenon as a response to the difference in income between developed and developing countries. The New Economics of Labor Migration (NEMT) theorizes it as a collective strategy between members of households in order to alleviate the adverse development situations that characterize developing countries and to improve the standard of living of households residing in the origin countries through remittances (Stark \& Bloom, 1985). In this context, the impact of remittances on development is becoming a topic of great attention among policy makers on both sides of countries, financial institutions and even researchers in this field.

Although there is little research on the impact of remittances on developed countries, immigration could have many benefits for these countries (Plaza, 2013; Constant and Zimmermann 2016; World Bank, 2016). Kharlamova and Sitnitskiy (2016) consider immigration to be a boon for them to take advantage of and not an economic burden for the host countries. The authors assert that the reception of immigrants is certainly expensive in the short term, but the benefits will be reaped in the medium term. These benefits can be summarized in a few points. First of all, immigration certainly affects the labor supply, but also the demand. Immigrants contribute to increasing the GDP of host countries by stimulating consumption, which, through their spending, will generate the potential creation of jobs. A recent study by Ortega and Peri (2008) found that a $1 \%$ increase in the labor force resulting from immigration also increased GDP by $1 \%$ to 14 countries of the Organization for Economic Co-operation and Development (OECD). Likewise, D'Albis et al. (2013) show that the immigration level has a favorable and important impact on GDP per capita, while the effects of immigration on unemployment are marginal. This is mainly due to the fact that immigrants occupy jobs often not filled by the aboriginal people (agriculture, construction, catering, security, and cleaning) which do not increase the level of unemployment in highincome destination countries (Breem, 2012). This implies that immigrants might not reduce wages and take jobs away from the aboriginal people (Blau \& Mackie, 2016; Constant, 2014; Peri, 2014; Zimmermann, 2017). This complementarity in the labor market between natives and immigrants can improve the productivity and economic activity in developed countries (Peri et al., 2015).

On the other hand, different impacts of migration and remittances on lowand middle-income recipient countries have been highlighted in the literature in recent years. The flow of migrants and remittances can positively affect various areas. Several studies show that the effectiveness of remittances in reducing poverty and inequalities is significant in the majority of the countries studied (Acosta et al., 2008; Akhter \& Islam, 2019; Azizi, 2019; Ekanayake \& Moslares, 2020; Fajnzylber \& López, 2008; Vacaflores, 2018). Thus, the receipt of remittances has a crucial impact on long-term economic growth through the accumulation 
of physical and human capital (Azizi, 2018; De Haas, 2006; Orozco, 2012). The authors show that international migrants have contributed significantly to the improvement of the standard of living of their households in the countries of origin through the expenditure of remittances and investments in the purchase of land, housing, and the creation of projects. In its 2006 report, the World Bank shows that the qualification level of migrants is linked by a higher remuneration in the host country, so the migrant member can transfer more money to their family, this further promotes investment in human capital. Thus, the migration of skilled workers can be a source of improvement in the level of education among members of households remaining in the origin countries. This helps to increase the stock of human capital, thus leading to brain gain rather than brain drain (Stark et al., 1998). Also, remittances help promote growth in countries where the financial sector is less developed. This proves that agents compensate for the lack of development of local financial markets by using remittances to alleviate liquidity constraints and to channel resources towards productive uses (Aggarwal et al., 2011; Coulibaly, 2015; Giuliano \& Ruiz-Arranz, 2005). Similarly, remittances are an important source to cover the balance of payments deficit in several countries. This is mainly due to the fact that these remittances constitute a more stable source of currency, unlike other capital flows, and they are used to finance imports (Leon-Ledesma \& Piracha, 2004; Ratha, 2004). Other studies discuss the hypothesis that remittances respond countercyclically to environmental and climate shocks (Alem et al., 2016; Sobczak-Szelc \& Fekih, 2020). Also, the return of skilled migrants to their home countries can facilitate the international transfer of technologies and knowledge that migrants can acquire during migration (Agrawal et al., 2011; Gibson \& McKenzie, 2014).

Moreover, migration also poses excessive dependency behaviors among remittance recipients (Acosta et al., 2009). The latter is generally observed by an increase in reserve wages when beneficiary household members prefer leisure to work. In this regard, our main interest is particularly focused on the effects of remittances on the labor market of developing countries.

In general, the effect of remittances on the decision to participate in the labor market is captured by the appreciation of macroeconomic variables such as the level of consumption and the level of investment. These economic variables are important transmission channels of the remittances in developing countries. In addition, studies interested in the impact of remittances on the labor supply of recipient households give very mixed results.

A number of studies confirm the negative effect in the case where transfer income substitutes labor income. In particular, Rodriguez and Tiongson (2001) conclude that remittances reduce labor market participation of Filipino households. The same conclusion was obtained by Gubert (2002) in the case of Mali. The author suggests that remittances act as insurance. Indeed, the availability of insurance reduces the work effort. In a study of the Mexican case, Airola (2005) focuses on the participation of family leaders in labor supply. It concludes a negative effect of remittances on hours' recipient households. Similarly, in the case of El Salvador, Acosta (2006) suggests that if leisure is an ordinary asset, it is expected that an exogenous increase in household income will increase recreational consumption. In 10 Latin American and Caribbean 
countries, Acosta et al. (2008) conclude that remittances have a negative effect on the overall supply of female labor in rural areas and the same effect on the number of hours worked per week in both urban and rural areas. Ndiaye et al. (2016) find that migration and remittances reduce the participation of recipient households in the labor market, supporting the reservation wage theory which could create a culture of dependency. Other studies such as Leon-Ledesma and Piracha (2004) and Jadotte (2009) show that remittances reduce the value of market wages for recipient households, particularly for women. This increases the reserve wage of workers belonging to households benefiting from these financial flows, allowing individuals to leave the labor market and increase their leisure consumption. The relationship between remittances and labor force participation in developing countries is also examined by Azizi (2018). The author concludes that remittances can increase human capital investments that increase the labor supply. But they can also increase reserve wages and reduce the participation rate of female beneficiaries in labor market participation. Gorlich et al. (2007) speak of a "disincentive effect". The authors indicate that living in a household with a migrant member is associated with a greater likelihood of being unemployed. The theoretical basis for the "disincentive effect" derives from the neoclassical labor supply theory. Mughal and Makhlouf (2013) show that migrant remittances raise the household's reserve wage and decrease labor participation. These household members prefer to consume more leisure time or allocate more time for production in family activities. Also, Abdulloev et al. (2014) show that there is a negative effect of remittances on men's labor market participation in Tajikistan. For the same country, Vadean et al. (2019) show that households with migrants can change their labor market status in response to remittances. The authors conclude that remittances decrease the rate of paid work and increase the rate of self-employment without changing the number of hours worked by households. Whereas, self-employment has a limited effect on economic development as it does not generate regular income. Also studying the case of Tajikistan, Murakami et al. (2021) estimate how migration and remittances influence labor market participation decisions. They show that the migration of a household member and the receipt of remittances reduce the labor supply of households with migrants by $5.4 \%$ and $10.2 \%$ respectively. Chami et al. (2018) suggest that migrant remittances appear to have a strong impact on both labor supply and demand. On the supply side, remittances reduce labor market participation and increase the informal work of recipient households. On the demand side, remittances reduce the overall unemployment rate.

Others show that the positive impacts of remittances have been recorded on productivity and employment through their effect on the investment channel. Thus, remittances have a microeconomic impact, which leads to an increase in the incomes of the families receiving and increase their propensity to consume. As a result, these migrants' financial flows lead to an increase in overall consumption of local goods (Naiditch \& Vranceanu, 2008). Similarly, the World Bank (2006) shows that remittances improve consumption and contribute to economic stability in the countries of origin by increasing investment by local firms in order to meet the labor market needs. Adams (2009) and Barajas et al. (2010) show that remittances have an effect on growth. They stimulate investment and increase participation in work and the productivity of inputs. Similarly, Woodruff and Zeneto (2001) and Woodruff (2007) 
suggest that remittances play an important role in the creation and financing of small firms. This creates a positive effect on investment and reduces the unemployment rate. Ahoure (2008) emphasizes the need for good governance for remittances from abroad to affect the country's GDP and reduce the unemployment rate. Drinkwater et al. (2003) show, first, that remittances to the origin countries increase the income of unemployed persons. But, if some remittances invest in the long term, then these financial flows can reduce the unemployment rate of the recipient countries. In the same context, Vadean et al. (2019) show that remittances linked by return migration can create employment opportunities in the home country's labor market through the creation of investment projects by the return migrants. This can particularly encourage self-employment among beneficiary households. According to the study by Murakami et al. (2021), remittances can smooth the liquidity constraints of households with a migrant member and increase investment opportunities in productive activities. Al-Mamun et al. (2015) also found a positive impact of migratory remittances on labor productivity. However, this effect appears to decrease as the amount of transfers exceeds a certain threshold. So, the authors show that there is an insignificant effect of remittances on labor productivity in countries where remittances are very high. Funkhouser (1992) notes that receiving money from abroad can reduce the participation rate due to the income effect. However, high levels of remittances to the local labor market can increase aggregate demand and also labor demand. In addition, Makhlouf (2018) shows that total factor productivity in Morocco has a positive response to an increase in remittances when these remittances exceed $5 \%$ of GDP.

Whereas, Cox-Edwards and Rodriguez (2008) show that remittances having a "neutral effect" on the labor market where these remittances are an integral part of a strategy, both of household to generate income and of migrants to send money to replace his loss of contribution to emigrate, so these remittances can act as insurance.

However, few studies have examined the effect of migrants' remittances on the labor market in Tunisia. These studies conclude that the evolution of these remittances has positive effects conditioned by other variables on the development of the Tunisian economy. In this regard, David and Marouani (2015) find that migration plays an important role in determining decisions to enter the Tunisian labor market. On the one hand, the exit of members of Tunisian households contributes to a decrease in the active population and consequently a decrease in the level of unemployment in the country. On the other hand, the participation of beneficiary households in the labor market recorded a significant increase in a response to the decline in remittances following the shock of the economic crisis in Europe, the main host region for Tunisian migrants. The same authors in 2018 (David \& Marouani, 2018) also analyze the different interactions between migration and labor supply participation after the Tunisian political revolution of 2011. The authors confirm the presence of a negative relationship on the unemployment of household members when the crisis negatively affects the amounts of remittances. Analyzing adaptation strategies, Edelbloude et al. (2017) show that remittances increase by absorbing the economic difficulties of the Tunisian revolution. These remittances serve as a safety net for the Tunisian labor market. In the same context, Makhlouf and Selmi (2021) confirm the 
stability of remittances during the post-revolutionary period that Tunisia is going through. For his part, Mesnard (2004), based on a survey study in the case of Tunisia, finds that return migration allows Tunisian households to adjust credit constraints, therefore, to invest in productive projects.

\section{Theoretical Model}

In this theoretical essay, we consider that migrant remittances are mainly oriented towards productive investment in the form of capital accumulation in the origin countries. Migration is one of the factors that lead to a change in both the population of an economy and participation in the labor market (Barro \& Sala-I-Martin, 1995).

\section{The Economic Context}

An economy that produces goods and services is considered to be both labor $(L)$ and capital $(K)$ according to the following constant output technology:

$$
Y=A F(K, L)=k^{\alpha}(A L)^{(1-\alpha)}, \quad 0<\alpha<1, \quad A>0
$$

With $Y, L, K, A$, and $\alpha$ are respectively the level of production, the labor which is approximated by the resident labor force (assuming that the work is homogeneous and individuals have the same skills and preferences), the stock of available capital in the economy, the labor productivity, and the elasticity of production relative to the level of capital.

A part of the labor force is therefore a migrant and regularly sends remittances. These remittances are mainly oriented towards productive investments in the form of capital accumulation in the countries of origin (Lucas, 1985).

In this essay. we studied the effect of remittances on labor supply at two levels: at the microeconomic level where we will study the effect of remittances on the labor supply for a representative resident household and at the macroeconomic level where we will analyze the effects of remittances on unemployment through the capital accumulation.

\section{Effect of Remittances on the Choice of Working Time of Resident Households ${ }^{1}$ : Microeconomic Effect}

We consider two individuals (resident member and migrant member) who live in two periods $\left(t_{1}\right.$ and $\left.t_{2}\right)$. This migratory movement is between two countries: a developing country of origin and a developed host country. In the first period $\left(t_{1}\right)$, residents of sending countries have the choice of staying in their country or leaving for a developed country in order to maximize their utility and that of their families.

\footnotetext{
1 This paragraph refers mainly to the models of (Chami et al., 2003; Naditch \& Vranceanu, 2008), with changes that we felt were necessary to our framework.
} 
The migrant receives an income $\left(w^{\mathrm{m}}\right)$ which is divided into two parts: a consumed part and a part saved and invested in their country of origin. Indeed, an increase in the migrant's wage may lead to an increase in the remittances to the country of origin. On the other hand, the resident receives a noted salary $\left(w^{r}\right)$ and chooses his rated work time $\left(h_{1}\right)$. In the second period $\left(t_{2}\right)$, the resident receives a salary $\left(w^{\mathrm{r}}\right)$ and a remittance from their migrant member in the host country $(T)$ (non-wage income). He chooses a time of the work noted $\left(h^{2}\right)$.

In our model, the resident and the migrant are subjected to a consumption-leisure arbitration that determines their labor supply. ${ }^{2}$ The resident utility function is written as follows:

$$
U_{t}^{r}=U\left(c_{t}, h_{t}\right)=c_{t}\left(1-h_{t}\right)
$$

With: $c_{t}$ and $h_{t}$ are, respectively, the consumption of the resident and their number of hours worked. The migrant utility function is as follows:

$$
V_{t}^{m}=V\left(x_{t}, \theta_{t}\right)=x_{t}\left(1-\theta_{t}\right)
$$

With: $x_{t}$ and $\theta_{t}$ are the consumption of the migrant and their number of hours worked, respectively. It is assumed that the migrant is altruistic (Bouhga-Hagbe, 2006). So it incorporates the utility of the resident. Its total utility is as follows:

$$
W_{t}=W\left(x_{t}, \theta_{t}, c_{t}, h_{t}\right)=\left[V\left(x_{t}, \theta_{t}\right)\right]^{1-\beta}\left[U\left(c_{t}, h_{t}\right)\right]^{\beta}
$$

With: $\beta$ is the degree of altruism, if $\beta=0$, therefore, the migrant is selfish, in our case $(\beta>0)$. Thus, we can write the inter-temporal (two-period) utilities of the resident and the migrant as follows:

$$
\begin{gathered}
Z^{r}=U\left(c_{1}, h_{1}\right)+U\left(c_{2}, h_{2}\right) \\
X^{m}=W_{1}+W_{2}=\left[V\left(x_{1}, \theta_{1}\right)\right]^{1-\beta}\left[U\left(c_{1}, h_{1}\right)\right]^{\beta}+\left[V\left(x_{2}, \theta_{2}\right)\right]^{1-\beta}\left[U\left(c_{2}, h_{2}\right)\right]^{\beta}
\end{gathered}
$$

Indeed, the budgetary constraints of the resident and the migrant take the following form:

$$
\begin{aligned}
& c_{t}=w^{r} h_{t}+T \\
& x_{t}=w^{m} \theta_{t}-T
\end{aligned}
$$

By following the Spence model (2002), the resident seeks to maximize $\left(Z^{r}\right)$, and the migrant seeks to maximize $X^{m}$. However, the main focus of the study is on the resident's strategy of containing the working time chosen in the two periods $\left(t_{1}\right)$ and

\footnotetext{
${ }^{2}$ It can be noted that the Cobb-Douglas form respects the neoclassical hypotheses concerning the convexity of preferences in the consumer-leisure space $\left({ }^{d U} / d b_{2}=0\right)$.
} 
$\left(t_{2}\right)$ and taking into account his salary and remittances from migrants. This strategy can be written as follows:

$$
S^{r}=\left\{\left(h_{1}, h_{2}\right) \perp\left(w^{r}, T\right)\right\}
$$

In the second period $\left(t_{2}\right)$, the recipient resident chooses the optimal number of hours worked, which depend on his salary and remittances. It seeks to maximize its second period utility as follows:

$$
\operatorname{Max} U\left(c_{2}\left(h_{2}\right), h_{2}\right)=\left(w^{r} h_{2}+T\right)\left(1-h_{2}\right)
$$

The utility function is optimal when $\left(d U / d h_{2}=0\right)$. Therefore, the optimal working time in the second period is written as follows:

$$
h_{2}^{*}=\frac{\left(-T / W_{W^{r}}+1\right)}{2}
$$

According to Eq. (11), we can see that in the second period, the participation of a resident at work increases with his salary. On the other hand, it is decreasing with non-wage incomes derived from remittances obtained from a migration decision from a family member in a developed country.

Similarly, to obtain the indirect utility of the resident in the second period, by replacing the supply of labor with Eq. (11) in the utility function Eq. (10), we obtain:

$$
U_{2}^{*}=U_{2}\left(T, w^{r}\right)=\max \left\{U\left(c_{2}\left(h_{2}\right), h_{2}\right)\right\}
$$

Indeed, the usefulness of the resident in the second period is written as follows:

$$
U_{2}\left(T, w^{r}\right)=\frac{1 / 4}{w^{r}}\left(T+w^{r}\right)^{2}
$$

In summary, the presence of income from a migrant abroad should increase the wages and purchasing power of recipient households. However, the developing economy suffers from a negative effect of remittances on the labor supply participation of households with migrants in the form of reduced hours worked by residents.

\section{Effect of Remittances on Labor Supply Through Capital Accumulation: Macroeconomic Effect}

We try to extend the model of Naiditch and Vranceanu (2008) in two directions. On the one hand, by making the dynamic model through the analysis of the impact of remittances on capital accumulation. And on the other hand, by modifying the capital stock through the effect of migratory remittances (Eq. (1)). Based on the work of Drinkwater et al. (2003) and Chami et al. (2003) which suggest that the phenomenon should be studied in two terms, to better analyze the effects of remittances since the capital accumulation and the realization of investment projects require a significant duration. In addition, the developing economy does not register a gain in capital transfers only in the long term, especially regarding 
their effect on labor market participation. In continuing our analysis, we are now studying the effect of remittances on capital accumulation in the origin countries. The output per unit of actual labor can be rewritten as follows:

$$
y=\frac{Y}{(A L)}=k^{\alpha}
$$

With: $k$ is the capital per person $\left(k=\frac{K}{A L}\right)$. Barro and Sala-I-Martin (1995) introduce the total labor force $(N)$ as an explanatory variable in the growth model. In the case of emigration, labor supply falls into two categories:

$$
L=N-M
$$

where: $L, N$, and $M$ are respectively the resident labor force, the total labor force, and the migrant labor force in a host country. Like Solow (1956), we assume that the national labor force $(N)$ and the migrant labor force $(M)$ grow at two different rates. With $(N)$ increases to an exogenous natural rate noted $(n)$ (population growth rate) and $(M)$ increases to an exogenous natural rate noted $(m)$, with:

$$
\frac{\dot{L}}{L}=n-m, \quad m=\frac{M}{N}
$$

We have the following equation:

$$
N=e^{n t} N_{0}, \quad M=e^{m t} M_{0}
$$

With: $N_{0}$ and $M_{0}$ are, respectively, the previous quantities of national and migrant workers. The total labor supply at a time $(t)$ is as follows:

$$
L_{t}=e^{n t} N_{0}-e^{m t} M_{0}
$$

In the case of emigration, the supply of capital $\left(K_{M}\right)$ consists of the physical capital $(K)$ and the transferred capital $(T)$, in the case of remittances contributing to economic development (for investment purposes). As a result, the supply of capital becomes:

$$
K_{(M)}=K+T
$$

The production function thus becomes in the following form:

$$
Y=A F(K, L)=(K+T)^{\alpha}(A L)^{1-\alpha}
$$

Moreover, if there is migration, capital per unit of actual labor is composed of two parts: the first refers to physical capital, and the second expresses the capital transferred by the migrants. Then, the equation becomes:

$$
k_{(M)}=\frac{(K+T)}{A L}, \quad k_{M}=k+t
$$

From this, the capital function per unit of actual labor can be rewritten as follows: 


$$
k_{(M)}=\frac{K+T}{A\left(e^{n t} N_{0}-e^{m t} M_{0}\right)}
$$

According to Eq. (22), we note that $k_{M}$ is an increasing function of the number of migrants and the remittances. In the long term, the physical capital and the transferred capital accumulate as a result of an investment effort. It assumes that the physical capital per capita and the capital transferred per migrant depreciate at a rate that is equal to $(\delta)$. Thus, labor productivity grows at a constant rate noted $(x)$.

- Equilibrium without emigration

Similar to growth models such as the Solow (1956) model and Barro and SalaI-Martin (1995) model, in the absence of migration, capital accumulation in a home country can be as follows:

$$
\dot{K}=s Y=\delta K
$$

Capital accumulates as a result of an investment effort which is the share of income noted $(s)$ and depreciates at a rate noted $(\delta)$. The function of capital accumulation per capita is as follows:

$$
\dot{k}=s k^{\alpha}-k(x+n+\delta)
$$

With: $(s)$ is the constant rate of saving and labor productivity $(A)$ increases at a constant rate noted $(x)$. So the per capita resident capital growth rate is as follows:

$$
g_{k}=\frac{\dot{k}}{k}=s k^{\alpha-1}-(x+n+\delta)
$$

In the steady state $g_{k}=0$, the equilibrium resident capital $\left(k^{*}\right)$ is given by the intersection between the curve $s k^{\alpha-1}$ and the horizontal line of the rate of depreciation of effective resident capital $(x+n+\delta),(x, n$, and $\delta$ are constants) (Barro $\&$ Sala-I-Martin, 1995). The equilibrium without emigration can be schematized using the following graph (Fig. 1):

At the beginning, the growth rate begins with a high level, then it decreases to reach the steady state at zero. Beyond the regular state, this rate becomes negative.

- Equilibrium with emigration

In the case of emigration, migrants bring the transferred capital to their origin country. Indeed, we can write the capital accumulation function as follows:

$$
\dot{K}_{(M)}=s Y-\delta(K+T)
$$




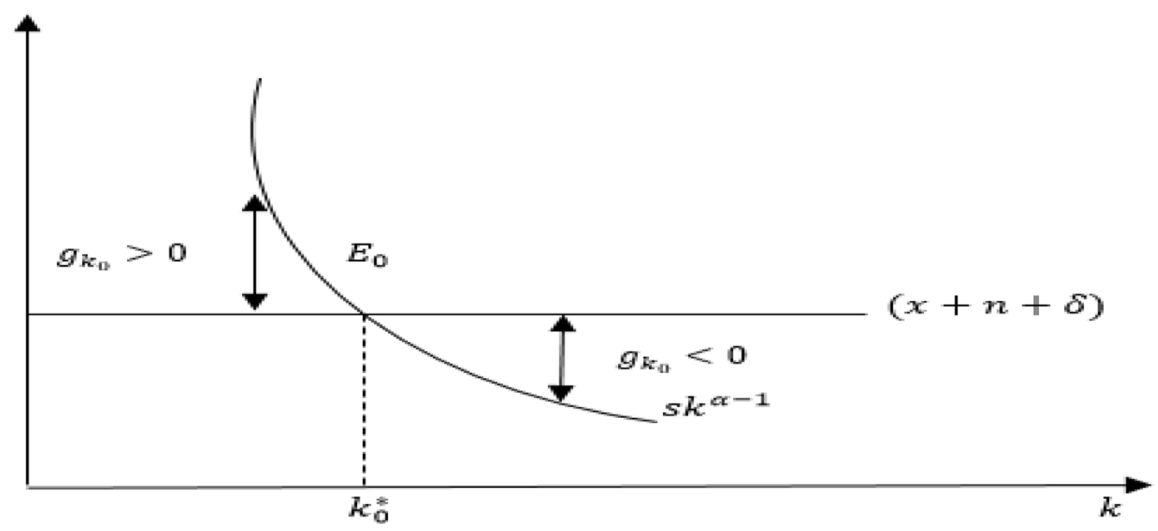

Fig. 1 The state of equilibrium in the case of absence of emigration. Source: Authors' own conceptualization

We suppose that $\left(\frac{K+T}{A L}=k+1\right)$ (Eq. (21)). Thus, the function of capital accumulation per capita is given by the following function:

$$
\dot{k}_{(M)}=s(k+t)^{\alpha}-(k+t)(x+n+\delta)
$$

The rate of growth of capital per unit of effective labor can be written as follows:

$$
g_{k_{(M)}}=s(k+t)^{\alpha-1}-(x+n+\delta)
$$

According to Barro and Sala-I-Martin (1995), the overall capital decline rate is equal to the sum of the effective labor growth rate $(x+n)$ plus the depreciation rate of the capital stock $(\delta)$. In equilibrium $g_{k_{(M)}}=0$, i.e. $s(k+t)^{\alpha-1}-(x+n+\delta)$ which corresponds to the intersection of the saving curve $\left(s(k+t)^{\alpha-1}\right)$ with the curve of the effective depreciation rate $(x+n+\delta)$. We suppose that the global capital per capita $(k+t)=_{k(M)}$, thus the derivative of $g_{k_{(M)}}$ with respect to $\left(k_{(M)}\right)$ is given by the following function:

$$
\frac{\partial g_{k_{(M)}}}{\partial k_{(M)}}=s(\alpha-1)\left(k_{(M)}\right)^{\alpha-2}<0
$$

The first derivative is negative ${ }^{3}$; therefore, the curve $\left(s(k+t)^{\alpha-1}\right)$ is decreasing with respect to $\left(k_{(M)}\right)$. Now we look for the shape of this curve:

$$
\frac{\partial^{2} g_{k_{(M)}}}{\partial^{2} k_{(M)}}=s(\alpha-1)(\alpha-2)\left(k_{(m)}\right)^{\alpha-3}>0
$$

\footnotetext{
${ }^{3}$ It is known that the quantity $(\alpha-1)$ is less than zero, since we assumed that $(\alpha)$ is always less than 1.
} 
The second derivative is positive, which indicates that the curve is convex, as shown in Fig. 2.

- The effect of remittances per migrant (t) on the level of income per capita (y).

Per capita income can be rewritten as follows:

$$
y=(k+t)^{\alpha}
$$

Any increase in remittances per capita $(t)$ can be assessed by the following derivative:

$$
\frac{\partial y}{\partial t}=\alpha(k+t)^{\alpha-1}>0
$$

It is clear that the sign of this derivative is positive. That is, any increase in the remittances per capita $(t)$ results in an increase in the income per capita $(y)$.

- The effect of remittances per migrant $(t)$ on the overall capital growth rate per capita $g_{k_{(M)}}$

We derive Eq. (28) with respect to $(t)$ in order to show the effect of an increase of $(t)$ on the growth rate. So the equation is as follows:

$$
\frac{\partial g_{k_{(M)}}}{\partial t}=s(\alpha-1)(k+t)^{\alpha-2}<0
$$

Equation (33) shows that the effect of remittances per capita $(t)$ is negative on the rate of capital growth. So when the remittances per capita $(t)$ increase, the saving effort can decrease and therefore the resident capital decreases, even when the global capital per capita $\left(k_{(M)}\right)$ increases.

- The effect of remittances per migrant (t) on resident capital per capita (k)

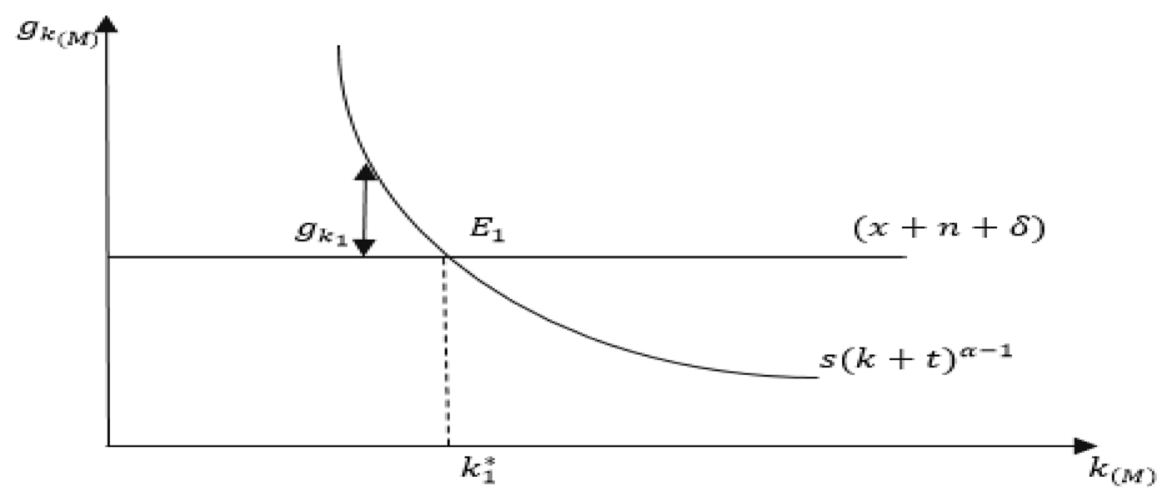

Fig. 2 The state of equilibrium in the case of emigration. Source: Authors' own conceptualization 
In steady state, the equilibrium capital $\left(k^{*}\right)$ is given by the equation $g_{k_{(M)}}=0$ in the following way:

$$
k^{*}=(s /(x+n+\delta))^{1 / 1-\alpha}-t
$$

The effect of the increase of remittances per capita $(t)$ on the resident capital per capita $\left(k^{*}\right)$ can be expressed as:

$$
\frac{\partial k^{*}}{\partial t}=-1<0
$$

An increase in remittances per capita $(t)$ therefore leads to a reduction in the equilibrium level of resident capital per capita $(k)$. This comes back to the substitution effect, when there is an increase in remittances from migrants, the national saving rate may decrease (Fig. 3).

This graph shows that the transition dynamics of $g_{k_{(M)}}$ and $k_{(M)}$ following an increase in migratory remittances per capita $(t)$ realize the equilibrium at point $\mathrm{E}_{2}$. Indeed, the growth rate that leads to this level of equilibrium is equal to $g_{k_{1}}$ which is less than $g_{k_{1}}$. Thus, an increase of $(t)$ makes it possible to move the curve $\left(s(k+t)^{\alpha-1}\right)$ to the right without the curve of the depreciation rate of the effective global capital $(x+n+\delta)$ moving. The equilibrium level increases from $\mathrm{E}_{1}$ to $\mathrm{E}_{2}$. Similarly, the level of global capital per capita increases from $k_{1}^{*}$ to $k_{2}^{*}$.

In conclusion, the impact of migratory remittances on the labor supply of recipient households, in the short term, is clearly identified through the determination of the time of the resident's participation in the labor supply. This participation decreases with transfers' income. In the long term, any increase in remittances has a positive effect on the level of income and total capital per capita and negatively on the resident capital per capita and the growth rate of the total capital per capita when allocated to productive investments. This result is consistent with the work of

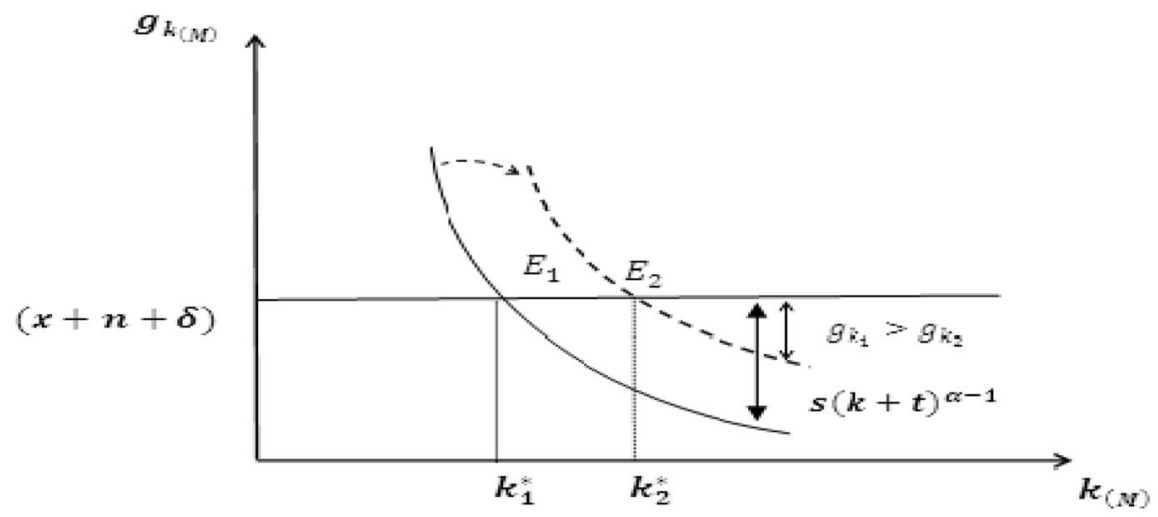

Fig. 3 The transition dynamics of $g_{k_{(M)}}$ and $k_{(M)}$ following the increase of $(t)$. Source: Authors' own conceptualization 
Chami et al. (2003), Drinkwater et al. (2003), and Damon (2009) which show that in the long term, remittances lead to an increase in the stock of capital that reduces unemployment in developing countries.

\section{Empirical Strategy}

\section{Econometric Models and Data}

Based on the theoretical studies presented in the previous section, we are trying to test an empirical validation that determines whether the impact of remittances on the level of unemployment of the countries of origin differs in the case whereby integrating the channel of demographic changes. In order to test our theoretical hypotheses, we chose to use the panel data to explore the impact of remittances on the labor effort provided by Tunisian residents benefiting from these funds since the panel regression is more precise when we have different temporal observations for each country. Moreover, in order to better explain this effect in the presence of demographic change, we use a model with simultaneous equations inspired by that of Schumann (2013). ${ }^{4}$ Indeed, we estimate three equations compatible with our theoretical work. These equations can be estimated separately, but the most important is that they are estimated simultaneously since the variables to be explained (migration, remittances, and unemployment) are strongly related.

Thus, these equations are based on macroeconomic data from the database of the National Institute of Statistics (INS), the Central Bank of Tunisia (BCT), the Ministry of Social Affairs (OTE ${ }^{5}$ ), and the World Bank (WDI) and cover the period between 1997 and 2017. The tests were conducted in the nine main host countries for Tunisian migrants in Europe (France, Italy, Germany, Belgium, Switzerland, Holland, Sweden, Austria, and England), which represented, in 2017, more than $88 \%$ of total migratory remittances in Tunisia (BCT).

The specification of the structural model can be written as follows:

$$
\begin{aligned}
\ln M I G_{t u n-i, t}= & a_{0}+a_{1} \ln \left(\frac{G D P_{i, t}}{G D P_{t u n, t}}\right)+a_{2} \ln U N E M P_{t u n, t}+a_{3} \ln U N E M P_{i, t} \\
+ & a_{4} \ln P O P_{t u n, t}+a_{5} \ln P O P_{i, t}+a_{6} \ln D I S T_{t u n, i}+a_{7} L A N G+\varepsilon_{1, t} \\
\ln R E M T_{i-t u n, t}= & b_{0}+b_{1} \ln G D P_{t u n, t}+b_{2} \ln G D P_{i, t}+b_{3} \ln U N E M P_{t u n, t} \\
& +b_{4} \ln I N T_{t u n, t}+b_{5} \ln I N F_{t u n, t}+b_{6} \ln C H A N G_{t u n, t}+ \\
& b_{7} \ln M I G_{t u n-i, t}+\varepsilon_{2, T}
\end{aligned}
$$

\footnotetext{
${ }^{4}$ See the study by Bourbonnais (2000) for more details on this methodology.

5 OTE: Office of Tunisians Abroad (www.ote.nat.tn).
} 


$$
\begin{aligned}
\ln U N E M P_{\text {tun }, t}= & c_{0}+c_{1} \ln G F C F_{\text {tun }, t}+c_{2} \ln R E M I T_{i-t u n, t} \\
& +c_{3} \ln I N F_{\text {tun }, t}+c_{4} \ln R E M I T_{i-t u n, t} \times \ln D E M O G_{t u n, t}+\varepsilon_{3, t}
\end{aligned}
$$

$\ln M I G_{t u n-i, t}, \ln R E M T_{i-t u n, t}$, and $\ln U N E M P_{\text {tun }, t}$ are, respectively, the stock of Tunisian emigrants in the country $i$ (With: $i=$ France, Germany, Italy, Belgium, Switzerland, Holland, Sweden, Austria, and England), the remittances from Tunisians to their country of origin and the unemployment rate in Tunisia.

The variables: $\ln =\left(\frac{G D P_{i, t}}{G D P_{t u n, t}}\right)$, $\ln U N E M P_{t u n}, \ln P O P_{t u n}, \ln P O P_{i}, \ln D I S T_{\text {tun }, i}$, $L A N G, \ln I N T_{\text {tun }}, \ln I N F_{\text {tun }}, \ln C H A N G_{\text {tun }}, \ln G F C F_{\text {tun }}, \ln R E M I T_{i-t u n, t} \times \ln D E M O G_{\text {tun }, t}$, and $\varepsilon_{t}$ denote, respectively, the ratio of the GDP per capita of country $i$ to the GDP per capita of Tunisia (to take account of income levels), the unemployment rate of country $i$, the total Tunisian population, the total population of country $i$, the distance that separates Tunisia from host country $i$, the cultural distance is measured by the common language which is a dummy variable that takes the value 1 if the French language is a language spoken in the host country and the value 0 otherwise, the Tunisian interest rate, the Tunisian inflation rate, the official Tunisian exchange rate, investment (GFCF), an interactive variable that measures the indirect effect of remittances on the level of unemployment through demographic changes (measured by the rate of population growth, according to the Solow (1956) model and an error term that follows the normal distribution) (Appendix, Table 2).

All of these variables are introduced in logarithmic form in the estimated models, allowing their coefficients to be interpreted as elasticities. Moreover, $c_{4}$ represents the interest parameter mainly used to emphasize the possibility of an indirect effect of remittances through demographic change on the level of Tunisian unemployment.

The identification test shows that our model is an over-identified model. As a result, the estimation methods that we can use in a model with simultaneous equations are triple least squares (3SLS), double least squares (2SLS) and the independent regressions method (SURE) (Bourbonnais, 2000). Moreover, we find that to produce good results, it is necessary to choose the triple least squares (3SLS) estimator which constitutes the effective method in this regard, giving a convergent and efficient estimator.

\section{Results and Discussion}

The main empirical results show that the main explanatory factors in the decision to emigrate are the income differential, the demographic factors and the cultural factors. The authors of the neoclassical theory remain faithful to Todaro's, 1970 explanation. This author considers that wage differentials between countries remain among the most important explanatory factors for the movement of workers. By following this explanation, we find that the income differential clearly appears to be a determinant of the great importance of their significant effect (threshold of significance equal to $1 \%$ ) that exerts on the decision of emigration of Tunisians to Europe. However, this variable has an unexpected effect which can be explained by the decrease in the income differential between countries does not always result in 


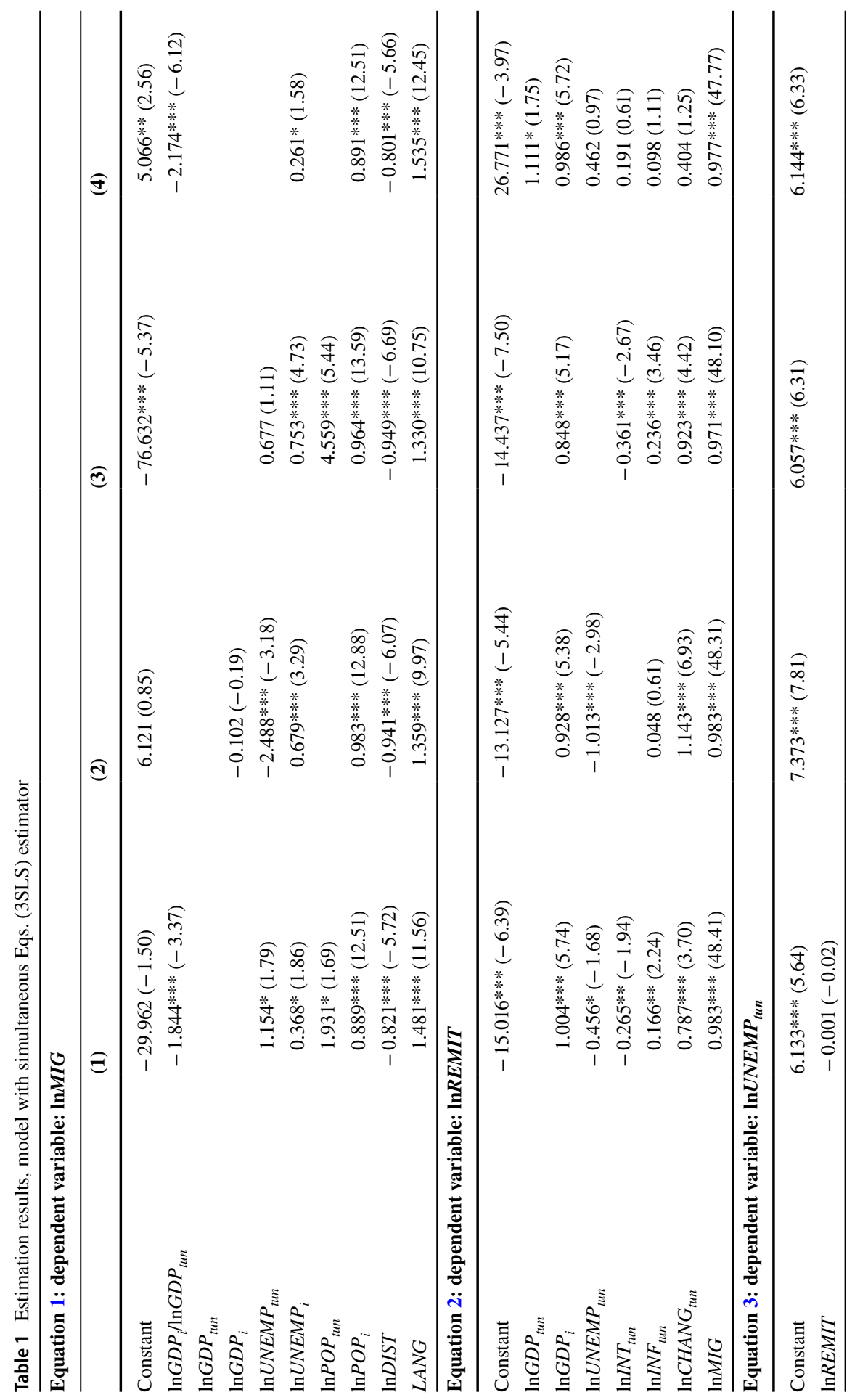




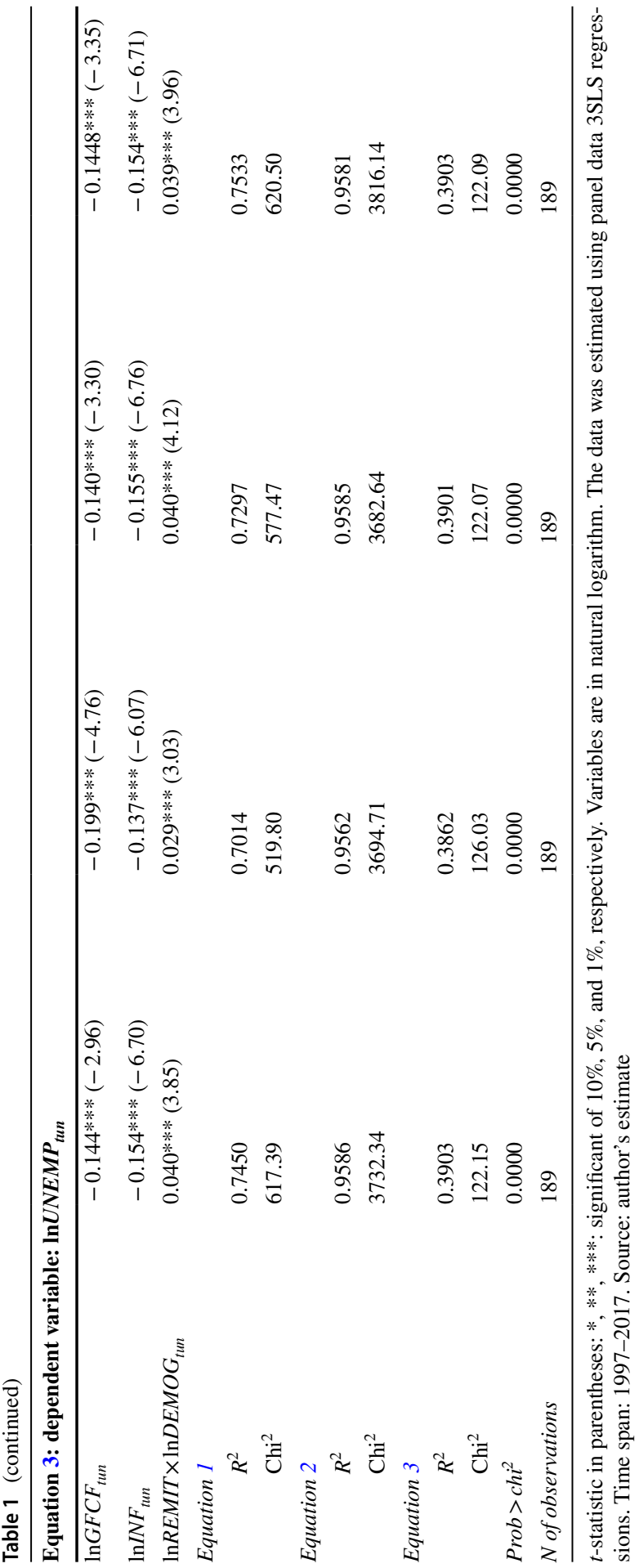


a decrease in the numbers of migrants to immigration countries. This arises in the case where income inequalities between households in the origin countries create a significant incentive to emigrate (Table 1).

Tunisian international migration is strongly correlated with demographic variables. Thus, demographic factors on both sides play a preponderant role in determining the decision to emigrate of Tunisians to European countries. In Tunisia, despite the low growth of the Tunisian population, which has registered a rate of $1.2 \%$ since 1990 (National Institute of Statistics (INS)), the additional demand for employment on the Tunisian labor market have exceeded those of the labor supply especially in recent years. Even, over the period between 1990 and 2010, the Tunisian economy recorded a relatively high growth rate equal to $5 \%$. However, for several economic and institutional factors, the Tunisian labor market remains constrained to absorb these additional demands, especially those of higher education graduates. This explains the rapid evolution of emigration to Europe. On the European side, the coefficients of the demographic factors are significant (significance threshold equal to $1 \%$ ) in all specifications. Indeed, the unexpected positive sign of this variable may be due, mainly to the fact that the countries of Europe suffer from a shortage of low or unskilled labor due to the great change in quantity and quality of human capital. This correlation therefore means that even if the population increases certain categories of the labor force are always requested, in accordance with (Peri, 2014; Zimmermann, 2017). The sharing the same language has a significant effect on the migration decision since mobility depends considerably on the language which reflects the ability to integrate (Korner, 1999). In our model, the common language to take into account cultural proximity is significant at the $1 \%$ threshold and has an expected positive sign regardless of the estimation technique used. It seems obvious that sharing the same language can facilitate emigration to developed countries.

The stock of Tunisian migrants is one of the main determinants of the remittances to Tunisia. The flow of migrants is significant at a threshold of $1 \%$, and their coefficient is very high and reaches almost $98 \%$ in all estimates. On average, the estimated level of elasticity is between 50 and 100\%, according to the study by Docquier and Machado (2015). It therefore seems that remittances are more dependent on the stock of migrants. Indeed, Tunisian migrants react more to the conditions linked by European countries than those in Tunisia. These conditions dominate the number of emigrants as an explanatory factor for the volume of remittances. For example, the coefficient is significant at the $1 \%$ threshold for income in the destination countries of Tunisian migrants, and their coefficient is very high in all the estimates and reaches more than $100 \%$. This result shows that the host country's GDP is one of the main determinants of remittances and supports the idea that the emigrant with significant financial capacity in the destination country sends more money to their families in the country of origin. In this context, Dustmann and Görlach (2016) see that a stable employment status of migrants in the host countries leads to an increase in remittances and also a significant accumulation of financial capital upon return to their home country.

The results also show that the direct effect of remittances on the level of Tunisian unemployment is statistically insignificant and with a negative sign (Fig. 4). This 


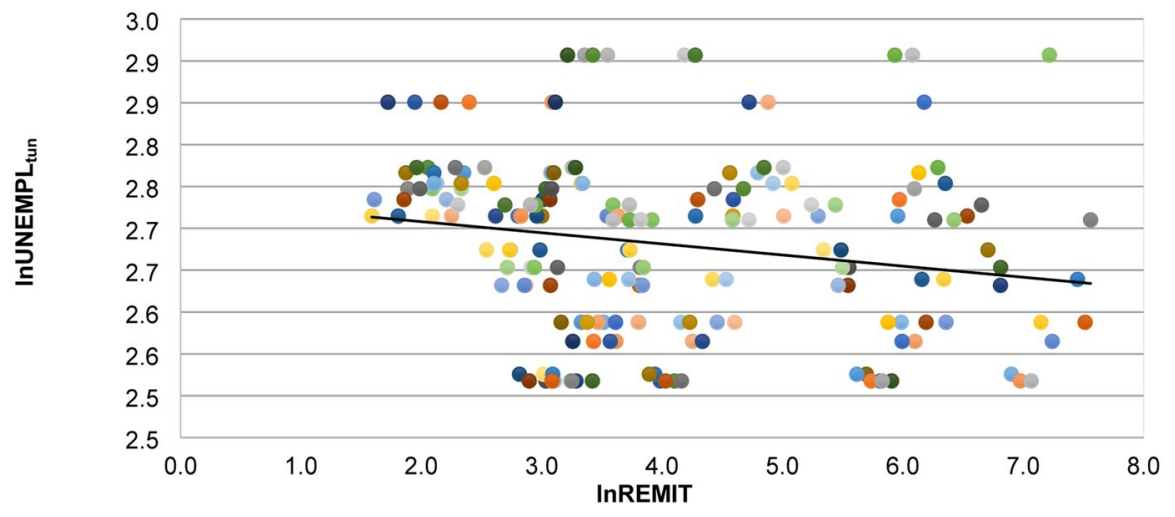

Fig. 4 The direct effect of remittances on the level of unemployment in Tunisia. Source: Author's presentation

implies that the amounts sent by Tunisian emigrants have only a small impact on the incentive for the participation of resident households in labor supply in Tunisia. This relationship was also found in Schumann's study, 2013 using a model with two simultaneous equations. Through an estimate of a fixed-effects model over a panel of 20 developing countries, Drinkwater et al. (2003) find that remittances have a negative and insignificant effect on unemployment. Thus, the authors find a negative elasticity $(-0.16$ and -0.01$)$ between the remittances and the level of unemployment. However, it is clear that there is an indirect effect of remittances on unemployment in Tunisia. The coefficient of the interactive variable exerts a positive effect and its significance threshold reach $1 \%$ (Fig. 5). The elasticity of this variable varies between 2.9 and $4 \%$ in all estimates. This indicates a low probability of not participating in the labor supply, but statistically remains significant. As a result, the demographic transition conditions the effects of remittances on the level of Tunisian

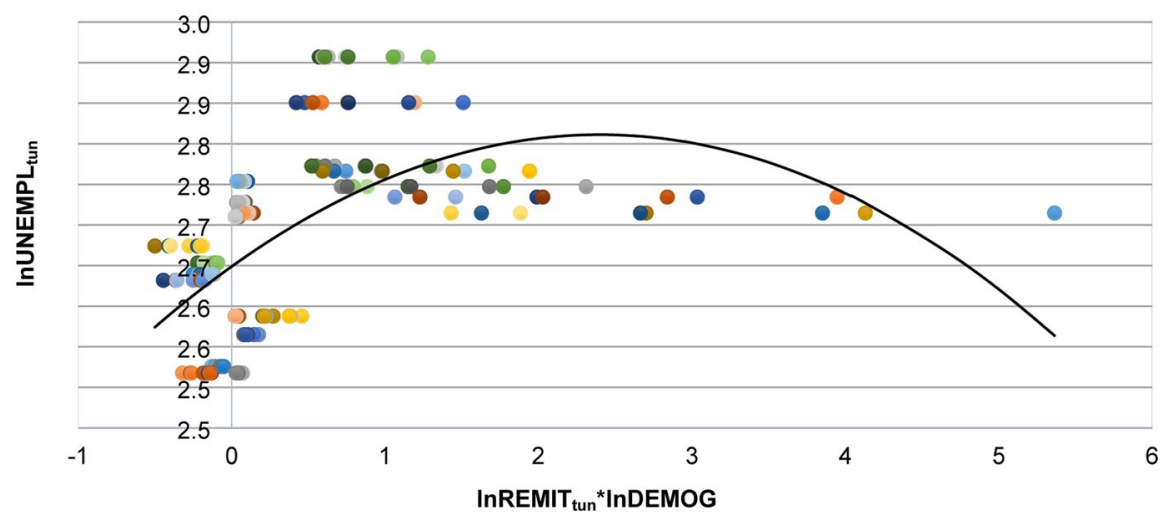

Fig. 5 The indirect effect of remittances on the level of unemployment in Tunisia through demographic changes. Source: Author's presentation 
unemployment. It is therefore clear that an increase in migratory remittances significantly reduces the labor supply and thus increases the unemployment level in the case of an aging population. This is because the workers receiving these funds spontaneously reduce their labor supply. This reduction therefore becomes increasingly clear when the population is getting older. These results suggest that households receiving remittances are about $4 \%$ less likely to participate in the Tunisian labor market. To better illustrate this effect, we have made estimates using the graphs as follows:

Figure 4 shows that the relationship between the remittances of Tunisian migrants and the country's unemployment level is rather small and decreasing ( $R^{2}$ is low). This correlation indicates that the flows of remittances from Tunisian migrants have a relatively small negative effect on the level of unemployment in Tunisia. Thus, any increase in remittances results in a small reduction in the unemployed level of Tunisians. This relationship becomes clearer by adding the demographic change as shown in Fig. 5. This variable contributes significantly to the increase in the unemployment rate in the case of Tunisia. This positive correlation reveals that the impact of demographic changes on the effect of remittances occurs through an increase in unemployment due to the aging of the population, which coincides with the case of Tunisia going through a period of demographic transition.

\section{Conclusions and Policy Implications}

In this work, we have focused on the effect of migratory remittances on the level of unemployment. Theoretically, these remittances influence the labor supply of recipient households in developing countries. On the one hand, if these remittances are invested productively, they can lead to the creation of jobs and reduce unemployment. On the other hand, they can create a "disincentive effect" on the labor market if the income from migratory remittances represents a substitution of labor income among recipient households of these flows.

Tunisia has been a country of emigration since the 1960s. The main destination for Tunisian migrants is Europe. These migrants have forged important economic ties with their country of origin. Empirically, we tested the correlation between migratory remittances and unemployment, taking into account demographic changes in the Tunisian case. Although, the data limitations restrict our empirical conclusions, our results are consistent and statistically robust. Our econometric study in the case of Tunisia leads to three main results. First, Tunisian migrants react more to economic conditions in European countries than in Tunisia. Thus, the conditions linked by the host countries constitute the main determinants of migration flows and, consequently, of remittances. In the event that the European region is affected by economic crises, this constitutes a threat to the stability of the amount of remittances to the least developed countries, including Tunisia. In this context, Stiglitz (2011) sees that the amount of remittances is considered as a channel of transmission of economic crisis from host countries to home countries. Secondly, the results prove the existence of a positive and significant indirect effect 
of remittances on the level of unemployment in the country through the demographic change of the Tunisian population. This result confirms that an increase in remittances clearly reduces the labor supply and thus increases the level of unemployment in the case of an aging population. So, the demographic transition conditions the effects of migratory remittances on the level of Tunisian unemployment. Third, our empirical results confirm the hypothesis of a positive relationship between migratory remittances and the level of Tunisian unemployment through the channel of demographic change. However, this conclusion conflicts with the "developmentist thesis" which accepts the hypothesis of a globally positive impact of remittances on developing economies. However, the overall impact of migratory remittances on the labor market cannot be negative because other indirect factors may also be at stake. An increase in consumption and investment as a result of remittances can stimulate domestic production leading to higher employment among households that do not benefit from remittances.

Therefore, some economic and political implications can be proposed as follows: the integration of migratory remittances into Tunisia's development policies is among the necessary priorities. The country's decision-makers can benefit more from the Tunisian migratory potential through the establishment of different means for Tunisian migrants to direct their remittances for investment purposes in their home country in order to increase the capital per capita and to reduce the level of unemployment in the coming years. This can be achieved through the adoption of a policy that strengthens social networks between migrants and their societies of origin. Some development programs encourage association projects between, for example, the unemployed and migrants. This association has two objectives. First, it can solve project financing difficulties, and second, it can promote investment. Also, Tunisia, in its strategies vis-à-vis its diaspora living abroad, should integrate the work on the awareness of migration policies, remittance policies, the organization of the labor market taking into account the needs of the Tunisia and the European countries. This can be a goal to increase formal remittances and generate better effects on Tunisia's economic growth. In this context, Tunisia, like many countries of the world, has become aware of the role played by migration as a major development solution. In addition, it developed a national migration strategy document in 2012. The update of this document in 2016 coincides with the preparation for the next five-year economic and social development plan for the next 5 years between 2016 and 2020. This migration strategy supports migration and financial flows from abroad in order to play an important role in the process of the country's economic transition. Moreover, the Tunisian diaspora is called upon to participate in the country's economic development through participation in remittances, investment efforts, national savings, and job creation (Tunisian National Migration Strategy, 2016). 


\section{Appendix}

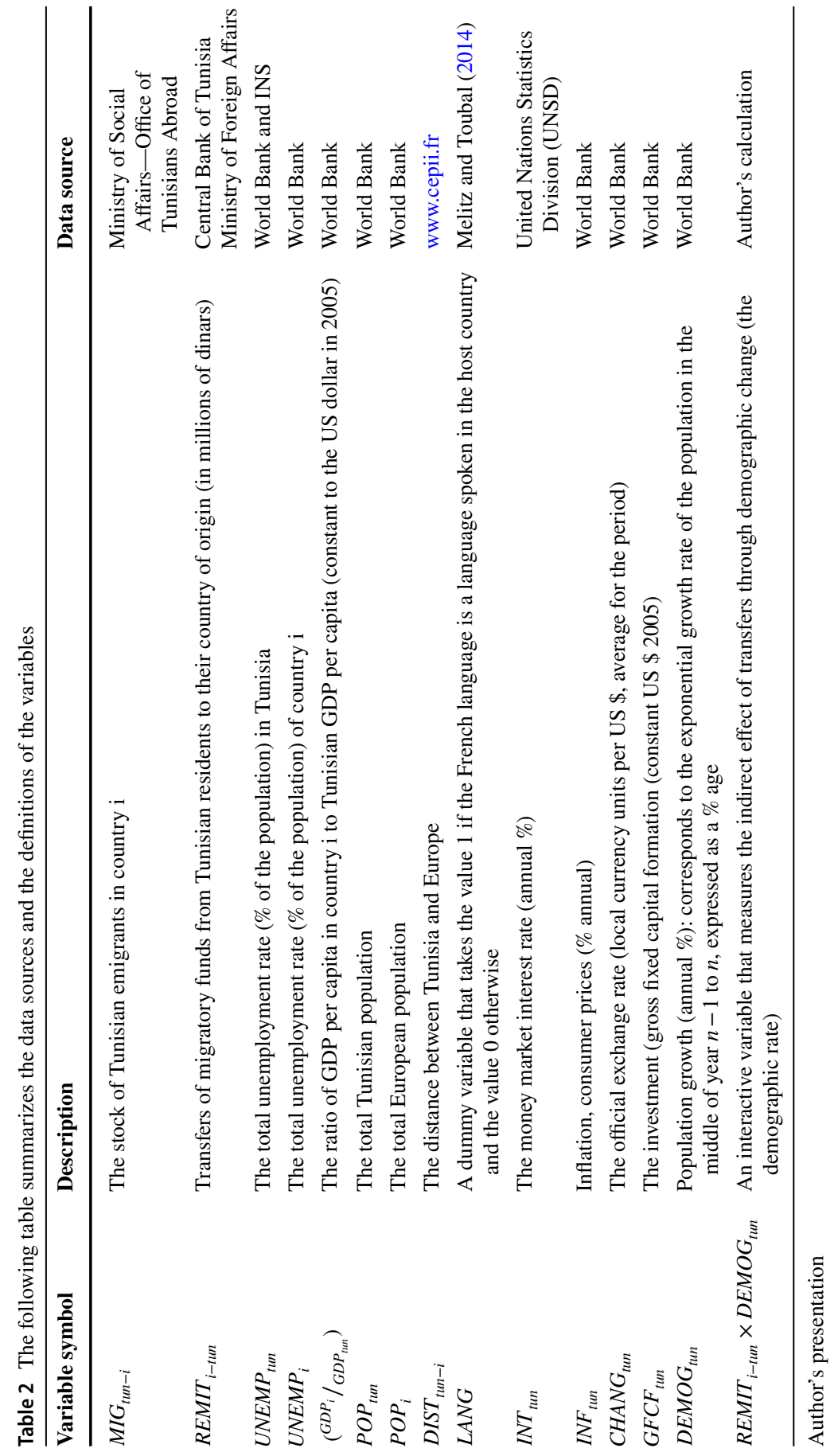


Author Contribution Hajer Habib is the author and sole main contributor to this article.

Availability of Data and Materials For data and analysis on migration and remittances: Tunisia: Ministry of Social Affairs — Office of Tunisians Abroad (OTE): http://ote.nat.tn/ and BCT: www.bct.gov.tn. The others variables: https://www.worldbank.org.

Code Availability Not applicable.

\section{Declarations}

Ethical Approval This paper does not contain any studies with human participants or animals performed by the author.

Informed Consent For this type of study, no formal consent is required.

Conflict of Interest The author declares no competing interests.

\section{References}

Abdulloev, I., Gang, I. \& Yun, M. (2014). Migration, education, and the gender gap in labour force participation. European Journal of Development Research, 26, 509-526. https://doi.org/10.1057/ejdr. 2014.27

Acosta, P. (2006). Labor supply, school attendance, and remittances from international migration: The case of El Salvador. World Bank, Policy Research Working Paper 3903. https://doi.org/10.1596/ 1813-9450-3903

Acosta, P. (2011). School attendance, child labour, and remittances from international migration in El Salvador. Journal of Development Studies, 47(6), 913-936. https://doi.org/10.1080/00220388.2011. 563298

Acosta, P., Calderón, C., Fajnzylber, P., \& Lopez, H. (2008). What is the impact of international remittances on poverty and inequality in Latin America? World Development, 36(1), 89-114. https://doi.org/10. 1016/j.worlddev.2007.02.016

Acosta, P., Lartey, E. K., \& Mandelman, F. S. (2009). Remittances and the Dutch disease. Journal of International Economics, 79(1), 102-116. https://doi.org/10.1016/j.jinteco.2009.06.007

Adams, R. (2009). The determinants of international remittances in developing countries. World Development, 37(1), 93-103. https://doi.org/10.1016/j.worlddev.2007.11.007

Adams, R., \& Cuecuecha, A. (2013). The impact of remittances on investment and poverty in Ghana. World Development, 50, 24-40. https://doi.org/10.1016/j.worlddev.2013.04.009

Adams, R., \& Page, J. (2005). Do international migration and remittances reduce poverty in developing countries? World Development, 33(10), 1645-1669. https://doi.org/10.1016/j.worlddev.2005.05.004

Aggarwal, R., Demirgüç-Kunt, A., \& Peria, M. S. (2011). Do remittances promote financial development? Journal of Development Economics, 96(2), 255-264. https://doi.org/10.1016/j.jdeveco.2010. 10.005

Agrawal, A., Kapur, D., McHale, J., \& Oettl, A. (2011). Brain drain or brain bank? The impact of skilled emigration on poor-country innovation. Journal of Urban Economics, 69(1), 43-55. https://doi.org/ 10.1016/j.jue.2010.06.003

Ahoure, A. (2008). Migrations, Transferts, Gouvernance Et Croissance Dans Les Pays d'Afrique SubSaharienne : Une Analyse À Partir De Données De Panel. IMI Workshop sur : Migrations, Liberté de Circuler et Développement. Rabat.

Airola, J. (2005). Labor supply in response to remittance income: The case of Mexico. Defense Resources Management Institute, Working Paper 2005/09.

Akhter, N. \& Islam, M. D. (2019). The impact of migration and migrant remittances on household poverty in Bangladesh. Asian Development Perspectives, 10(1), 43-59. https://doi.org/10.22681/ADP. 2019.10.1.43 
Alem, Y., Maurel, M. \& Millock, K. (2016). Migration as an adaptation strategy to weather variability: An instrumental variables probit analysis. University of Gothenburg. Working Papers in Economics, p. 665.

Al-Mamun, M., Sohag, K., Uddin, G., \& Shahbaz, M. (2015). Remittance and domestic labor productivity: Evidence from remittance recipient countries. Economic Modelling, 47, 207-218. https://doi. org/10.1016/j.econmod.2015.02.024

Azizi, S. (2018). The impacts of workers' remittances on human capital and labor supply in developing countries. Economic Modelling, 75, 377-396. https://doi.org/10.1016/j.econmod.2018.07.011

Azizi, S. (2019). The impacts of workers' remittances on poverty and inequality in developing countries. Empirical Economics, 60(2), 969-991. https://doi.org/10.1007/s00181-019-01764-8

Barajas, A., Chami, R., Hakura, D. \& Montiel, P. (2010). Workers' Remittances and the Equilibrium Real Exchange Rate: Theory and Evidence. Department of Economics Working Papers, No 2010-12.

Barro, R. J., \& Sala-i-Martin, X. (1995). Economic Growth. Mc Graw-Hill.

Bettin, G., Presbitero, A. \& Spatafora, N. (2014). Remittances and vulnerability in developing countries. International Monetary Fund, Working Paper WP/14/13.

Blau, F. D., \& Mackie, C. (2016). The economic and fiscal consequences of immigration. A Report of the National Academies.

Bouhga-Hagbe, J. (2006). Altruism and workers' remittances: Evidence from selected countries in the Middle East and Central Asia. International Monetary Fund, Working Paper 06/130, Washington, D.C

Bourbonnais, R. (2000). Econométrie. Dunod.

Breem, Y. (2012). L'insertion professionnelle des immigrés et leurs descendants en 2010. Info migrations, n³1, 2012, Secrétariat général à l'immigration et à l'intégration.

Chami, R., Ernest, E., Fullenkamp, C. \& Oeking, A. (2018). Are remittances good for labor markets in LICs, MICs and fragile states? Evidence from cross-country data. International Monetary Fund, WP/18/102

Chami, R., Fullenkamp, C. \& Jahjah, S. (2003). Are immigrant remittance flows a source of capital for development? International Monetary Fund, Working Papers 03/189.

Constant, A.F. (2014). Do migrants take the jobs of native workers? IZA World of Labor, 10. https://doi. org/10.15185/izawol.10

Constant, A. F., \& Zimmermann, K. F. (2016). Diaspora Economics: New perspectives. International Journal of Manpower, 37(7), 1110-1135. https://doi.org/10.1108/IJM-07-2016-0151

Coulibaly, D. (2015). Remittances and financial development in Sub Saharan African countries: A system approach. Economic Modelling, 45, 249-258. https://doi.org/10.1016/j.econmod.2014.12.005

Cox-Edwards, A., \& Rodríguez, O. E. (2008). Remittances and labor force participation in Mexico: An analysis using propensity score matching. World Development, 37(5), 1004-1014. https://doi.org/10. 1016/j.worlddev.2008.09.010

D’Albis, H., Boubtane, E. \& Coulibaly, D. (2013). Immigration et croissance économique en France entre 1994 et 2008. CERDI Working Papers, 201305, 23.

Damon, A. (2009). Household labor allocation in remittance-receiving households: The case of El Salvador. https://www.oecd.org/development/pgd/43084079.pdf

David, A., \& Marouani, M. A. (2015). Migration and employment interactions in a crisis context: The case of Tunisia. Economics of Transition, 23(3), 597-624. https://doi.org/10.1111/ecot.12074

David, A. \& Marouani, M.A. (2018). Migration patterns and labor market outcomes in Tunisia. Book chapter 10: The Tunisian labor market in an era of transition. Edited by Ragui Assaad and Mongi Boughzala, Oxford University Press. https://doi.org/10.1093/oso/9780198799863.003.0010

De Haas, H. (2006). Migration, remittances and regional development in Southern Morocco. Geoforum, 37(4), 565-580. https://doi.org/10.1016/j.geoforum.2005.11.007

Docquier, F. \& Machado, J. (2015). Remittance and migration prospects for the twenty-first century. FERDI Working Papers P-133.

Drinkwater, S., Levine, P. \& Lotti, E. (2003). The labour market effect of remittances. Hamburg Institute of International Economics, FLOWENLA Discussion paper 6.

Dustmann, C., \& Görlach, J. S. (2016). The economics of temporary migrations. Journal of Economic Literature., 54(1), 98-136. https://doi.org/10.1257/jel.54.1.98

Edelbloude, E., Fontan-Sers, C. \& Makhlouf, F. (2017). Do remittances respond to revolutions? The evidence from Tunisia. Research in International Business and Finance, 42(C), 94-101. https://doi. org/10.1016/j.ribaf.2017.04.044 
Ekanayake, E. M. \& Moslares, C. (2020). Do remittances promote economic growth and reduce poverty? Evidence from Latin American countries. Economies, 8(2), 1-26. https://doi.org/10.3390/ economies 8020035

Fajnzylber, P. \& López, J. H. (2008). Remittances and development: Lessons from Latin America. Washington, DC: World Bank. Retrieved December 2020, from https://openknowledge.worldbank.org/ handle/10986/6911

Freund, C. \& Spatafora, N. (2005). Remittances: Transaction costs, determinants, and informal flows. World Bank, Policy Research Working Paper 3704, Washington D.C.

Funkhouser, E. (1992). Migration from Nicaragua: Some recent evidence. World Development, 20(8), 1209-1218.

Gagnon, J. (2020). COVID-19: Consequences for international migration and development. Paris: OECD. Retrieved December 2020, from https://oecd-developmentmatters.org/2020/04/02/COVID19consequences-forinternational-migration-and-development/

Gibson, J., \& McKenzi, D. (2014). Scientific mobility and knowledge networks in high-emigration countries: Evidence from the Pacific. Research Policy, 43(9), 1486-1495. https://doi.org/10.1016/j. respol.2014.04.005

Giuliano, P. \& Ruiz-Arranz, M. (2005). Remittances, financial development and growth. International Monetary Fund, Working Paper No. 05/234.

Gorlich, D., Mahmoud, T. \& Trebesch, C. (2007). Explaining labour market inactivity in migrant-sending families: Housework, hammock, or higher education. Kiel Institute for the World Economy, Working Papers 1391.

Gubert, F. (2002). Do migrants insure those who stay behind? Evidence from the Kayes Area (Western Mali). Oxford Development Studies, 30(3), 267-287. https://doi.org/10.1080/1360081022000012699

Harris, J. R., \& Todaro, M. P. (1970). Migration, unemployment and development: A two-sector analysis. The American Economic Review, 60(1), 126-142.

Jadotte, E. (2009). International migration, remittances and labour supply: The case of the Republic of Haiti. World Institute for Development Economic Research, Working Papers (UNU-WIDER).

Jennissen, R. (2000). Can economic determinants improve the theoretical background for international migration hypotheses? Netherlands Interdisciplinary Demographic Institute (NIDI). WP n, 2, 1-39.

Kharlamova, G. \& Sitnitskiy, M. (2016). Growing regional scientific migration and mobility: The European Union and the eastern partnership. Retrieved November 2021, from, http://cse.uaic.ro/eurint/ proceedings/index_htm_files/EURINT\%202016_KHA.pdf

Korner, H. (1999). Pays en développement : La fuite des cerveaux-continue. Problèmes Économiques, No, 2656-2657, 73-76.

Leon-Ledesma, M., \& Piracha, M. (2004). International migration and the role of remittances in Eastern Europe. International Migration, 42(4), 65-83. https://doi.org/10.1111/j.0020-7985.2004.00295.x

Lucas, R. (1985). Mines and migrants in South Africa. The American Economic Review, 75(5), 1094-1108.

Majeed, M. (2015). Poverty effects of remittances: A comparative analysis. Journal of International Development, 27(1), 1-14. https://doi.org/10.1002/JID.3055

Makhlouf, F. (2018). Is productivity affected by remittances? The evidence from Morocco. Journal of International Development, 31(2), 211-222. https://doi.org/10.1002/jid.3398

Makhlouf, F., \& Selmi, R. (2021). The role of remittances in times of socio-political unrest: Evidence from Tunisia. ffhal-03263815v2f. https://doi.org/10.13140/RG.2.2.31503.51369

Melitz, J., \& Toubal, F. (2014). Native language, spoken language, translation and trade. Journal of International Economics, 93(2), 351-363. https://doi.org/10.1016/j.jinteco.2014.04.004

Mesnard, A. (2004). Temporary migration and self-employment: Evidence from Tunisia. Brussels Economic Review, 47(1), 119-138.

Mughal, M., \& Makhlouf, F. (2013). Labour effects of foreign and domestic remittances -Evidence from Pakistan. International Review of Applied Economics, 27(6), 798-821. https://doi.org/10.1080/02692171. 2013.804495

Murakami, E., Yamada, E., \& Sioson, E. (2021). The impact of migration and remittances on labor supply in Tajikistan. Journal of Asian Economics, 73, 101-268. https://doi.org/10.1016/j.asieco.2020. 101268

Naiditch, C., \& Vranceanu, R. (2008). Transferts des migrants et offre de travail dans un modèle de signalisation. Revue D'economie Politique, 118(4), 513-540. https://doi.org/10.3917/redp.184.0513

National Institute of Statistics of Tunisia (INS). http://www.ins.tn 
Ndiaye, A. S., Niang, O. K., Ndione, Y. C. \& Dedehouanou, S. E. A. (2016). Migration, remittances, labour market and human capital in Senegal. Working paper, 2016-10

Orozco, M. (2012). Remittances and well-being In Book: International Encyclopedia of Housing and Home 28-34. https://doi.org/10.1016/B978-0-08-047163-1.00050-3

Ortega, F., \& Peri, G. (2008). The causes and effects of international labor mobility: Evidence from OECD countries 1980-2005. Human Development Research Paper, 2009(06), 2008.

Özden, Ç. \& Schiff, M. (2007). International migration, economic development and policy. Trade and Development. Washington, DC: World Bank and Palgrave Macmillan. https://openknowledge. worldbank.org/handle/10986/6766

Peri, G. (2014). Do immigrant workers depress the wages of native workers? IZA World of Labor, 42.

Peri, G., Shih, K., \& Sparber, C. (2015). STEM workers, H-1B visas and productivity in US cities. Journal of Labor Economics, 33(S1), S225-S255. https://doi.org/10.1086/679061

Plaza, S. (2013). Diaspora resources and policies. In Constant AF. and Zimmermann KF, 505-529.

Ratha, D. (2004). Understanding the importance of remittances. Migration Information Source, World Bank, Washington, DC.

Ratha, D. (2005). Remittances: A lifeline for development. International Monetary Fund, Finance and Development, $42,4$.

Rodriguez, E. R., \& Tiongson, E. R. (2001). Temporary migration overseas and household labor supply: Evidence from urban Philippines. International Migration Review, 35(3), 709-725. https://doi.org/ 10.1111/j.1747-7379.2001.tb00037.x

Schumann, N. (2013). Differential labor supply response to remittances with respect to human capital. University of Zurich.

Sobczak-Szelc, K. \& Fekih, N. (2020). Migration as one of several adaptation strategies for environmental limitations in Tunisia: Evidence from El Faouar. Comparative Migration Studies, 8(8). https:// doi.org/10.1186/s40878-019-0163-1

Solow, R. M. (1956). A contribution to the theory of economic growth. Quarterly Journal of Economics, 70(1), 65-94. https://doi.org/10.2307/1884513

Spence, M. (2002). Signaling in retrospect and the informational structure of markets. The American Economic Review, 92(3), 434-459. https://doi.org/10.1257/00028280260136200

Stark, O., \& Bloom, D. E. (1985). The new economics of labor migration. The American Economic Review, 75(2), 183-178.

Stark, O., Helmenstein, C., \& Prskawetz, A. (1998). Human capital depletion, human capital formation, and migration: A blessing or a "curse"? Economics Letters, 60(3), 363-367.

Stiglitz, J.E. (2011). Le triomphe de la cupidité. Essai traduit de l'américain par Paul, ISBN 978-2-7427-9504-8.

Todaro, M. (1970). Labor migration and urban unemployment: Reply. American Economic Review, 60(1), 187-188. https://www.jstor.org/stable/i331370

Tunisian National strategy for migration. (2016). 2030 Agenda migration-relevant and related target labels. Ministry of Social Affairs. Retrieved June, 2019, from http://ote.nat.tn/wp-content/uploads/2018/05/SNM_FRA_ FINALE.pdf

Vacaflores, D. E. (2018). Are remittances helping lower poverty and inequality levels in Latin America? Quarterly Review of Economics and Finance, 68, 254-265. https://doi.org/10.1016/j.qref.2017.09. 001

Vadean, F., Randazzo, T., \& Piracha, M. (2019). Remittances, labour supply and activity of household members left-behind. Journal of Development Studies, 55(2), 278-293. https://doi.org/10.1080/ 00220388.2017 .1404031

Woodruff, C. (2007). Mexican microenterprise investment and employment: The role of remittances. Inter-American Development Bank, Intal - ITD, Working Paper, (26).

Woodruff, C. \& Zeneto R. (2001). Remittances and microenterprises in Mexico. UCSD, Graduate School of International Relations and Pacific Studies, Working Paper.

World Bank (2020). COVID-19 crisis: Through a migration lens. Migration and Development Brief 32, Migration and Remittances Team Social Protection and Jobs, World Bank Group and KNO$M A D$. Retrieved November 2020, from https://www.knomad.org/publication/migration-anddevelopment-brief-32-COVID-19-crisis-through-migration-lens

World Bank (2019a). Migration and remittances: Recent developments and outlook. Retrieved November 2020, from https://www.knomad.org/publication/migration-and-development-brief-31

World Bank (2016). Migration and development. Washington, DC. 
World Bank (2006). Global economic prospects - Economic implications of remittances and migration. The International Bank for Reconstruction and Development.

Yang, D. (2008). Coping with disaster: The impact of hurricanes on international financial flows, 19702002. The B.E. Journal of Economic Analysis \& Policy, 8(1), 1-45. https://doi.org/10.2202/19351682.1903

Zimmermann, K. F. (2017). Refugee and migrant labor market integration: Europe in need of a new policy agenda. in Bauböck R. and Tripkovic M. The integration of migrants and refugees. An EUI Forum on Migration, Citizenship and Demography, European University Institute, Robert Schuman Centre for Advanced Studies, Florence, 88-100.

Zimmermann, F. (1996). European migration: Push and pull. International Regional Science Review, 19(1-2), 95-128. https://doi.org/10.1177/016001769601900211

Publisher's Note Springer Nature remains neutral with regard to jurisdictional claims in published maps and institutional affiliations.

Hajer Habib Hajer Habib holds a PhD in Economics and a Master degree in Development Economics from the University of Tunis El-Manar, Tunisia. Her current research focuses on International migration, International finance, and Development economics 